\title{
E-commerce as a Consequence of Innovation and the Cause of New Innovations for SMEs: the Perspectives of Latvia and Lithuania
}

\author{
Baiba Rivza \\ Prof., dr. hab. oec., Latvia University of Life Sciences and Technologies \\ Jelgava, Latvia \\ e-mail: baiba.rivza@llu.Iv
}

\section{Maiga Kruzmetra}

Senior researcher, Latvia University of Life Sciences and Technologies

Jelgava, Latvia

e-mail: maiga.kruzmetra@llu.Iv

\section{Peteris Rivža}

Prof., dr. sc. hab. ing., Latvia University of Life Sciences and Technologies

Jelgava, Latvia

e-mail: peteris.rivza@llu.Iv

\section{Astrida Miceikiene}

Prof., dr., Vytautas Magnus University, Kaunas, Lithuania

e-mail: astrida.miceikiene@edu.It

\author{
Alvydas Balezentis \\ Prof., dr., Mikolas Romeris University, Vilnius, Lithuania \\ e-mail: a.balezentis@gmail.com \\ Jonas Jasaitis \\ Prof., dr., Šiauliu University, Šiauliai, Lithuania \\ e-mail:moksolietuva@gmail.com
}




\section{Abstract}

The emergence of new technologies and the expansion of digitalisation have created an opportunity for e-commerce to develop. A supplier and a buyer of goods and services meet in the e-environment and solve their problem without direct contact, which is mutually beneficial. Accordingly, when it comes to globalisation, e-commerce, as a system, becomes an important topic of research in general, and, in particular, it is vital for small and medium enterprises (SMEs), since most enterprises in the European Union (EU) are SMEs. Latvia and Lithuania are EU Member States, and SMEs are dominant in these two Baltic States. The aim of the research is to identify and compare the opinions of producers/sellers and buyers on the positive contribution of e-commerce to date and the problems caused by e-commerce for both sides. The research employed data from Eurostat, OECD and the Central Statistical Bureau of Latvia as well as the authors' own data from a survey (e-commerce users: suppliers $(n=112)$ and buyers ( $n=138$ ) of goods and services) conducted in Latvia and Lithuania. An analysis of the statistical data reveals the current objective position of e-commerce in both countries. The proportion of small and medium enterprises involved in this process is increasing. At the same time, the processing of the results of the e-commerce survey enables the authors to see a subjective view of this process, which includes both positive and negative features of both the buyers and the sellers. Identifying problems and comparing the situations in the two neighbouring countries opens the way to find e-commerce development directions and reduce the problems not only economically but also geographically and ethnically, as the objective data on e-commerce are not identical for Latvia and Lithuania, even though the data are positive and only slightly different.

Keywords: e-commerce, SMEs, innovation, motivation

JEL: M37, 014

\section{Introduction}

Europe 2020 is the European Union's strategy for smart, sustainable and inclusive growth. Smart growth refers to an economy based on knowledge and innovation as drivers of future growth. The flagship initiative for smart growth, called "A Digital Agenda for Europe", prescribes the ultra-fast creation of information and communication technology systems, which also takes into consideration the growing effect of the European Digital Single Market (EC 2010). Even though the digital economy is growing faster than the economy as a whole (EC 2014), the expected European Digital Single Market is not developing sufficiently fast. The Digital Economy and Society Index (DESI) was designed to assess the digitalisation process, and since 2004, it has measured the progress of the EU Member States towards a digital economy and society, yet some changes have occurred in the digitalisation process (EC 2018a). On 10 May 2017, the European Commission published a mid-term review of the Digital Single Market Strategy. It presents and evaluates the progress in implementing the Strategy since 
2015 and highlights where further actions are needed (data economy, cybersecurity and online platforms) (EC 2017). However, according to the European Ecommerce Association (EMOTA), Internet use and online shopping differ strongly across the EU Member States (European Ecommerce Report 2018).

E-commerce as a phenomenon attracts the attention of policy-makers and prompts activity in research on the e-environment, e-skills and, of course, the effects of e-commerce on the social and economic activity of individuals. Research has revealed that business patterns transform under digitalisation (Schallmo et al. 2017; Byungjoon and Moonkyoung 2019), or the transformation occurs in a particular segment of the economy, e.g. agriculture (GFA 2018). Research has found that e-commerce has expanded in the key EU Member States (Raisová and Curpová 2014). At the same time, a number of authors have pointed to the unbalanced development of innovation both among countries and within some countries (Raisová and Curpová 2014; Pytkowska and Korynski 2017). A significant focus in the research is placed on analysing the effects of technologies, and digitalisation in particular, on the working world. The term "Industry 4.0" has led to the term "labour 4.0" (Grass and Weber 2017). One of its features is the expanding scope of work on digital or online platforms (Waas et al. 2018). The challenges of working on online platforms were extensively discussed at the Trade Union Forum (TUAC 2017). The International Labour Organisation (ILO) has done extensive research into digital labour platforms and the future of work, which require from individuals another level of thinking, knowledge and skills (Berg et al. 2018). Work on digital or online platforms explicitly indicates the e-commerce system in an economy.

Small and medium enterprises (SMEs) in the EU constitute most of the total number of enterprises, and they are dominant in Latvia and Lithuania (Eurostat 2018). Therefore, an analysis of the factors that promote or hinder SMEs is crucial from the perspective of opportunities for their economic development. As e-commerce expands, the authors have set the aim of identifying and then comparing the opinions of manufacturers and consumers on their involvement in this system in the two small Baltic States. In particular, the authors aim to explore the positive contribution that e-commerce has made to date and, at the same time, to identify the problems posed by the established e-commerce system and which arise from economic cooperation between both sides. A specific research task was also to make a cross-country comparison to look for positive experiences in the functioning of the e-commerce system in either country.

The research employed data from Eurostat, the OECD and the Central Statistical Bureau of Latvia, as well as the authors' own data from a survey (e-commerce users of goods and services: suppliers ( $\mathrm{n}=112$ : 95 in Latvia and 17 in Lithuania) and buyers ( $n=138$ : 61 in Latvia and 77 in Lithuania)) conducted in Latvia and Lithuania. The survey was carried out in 2018. Despite the fact that the sample groups were not representative (did not reflect the views of the entire population groups as entrepreneurs and consumers), the obtained data and results of this analysis provided an insight into supply and the demand in e-commerce, stressing the problems to be tackled. 


\section{Results and discussion}

Latvia and Lithuania have been EU Member States since 2004. One of the goals of their accession to the EU was to achieve at least the average social development level of the EU. It could be achieved only by successful economic growth, including digitalisation. The performance of the economy in relation to digitalisation is measured by the DESI index, which shows the progress of the EU Member States towards the digital economy and society. The index shows the situations in all the EU Member States, which gives an opportunity to compare individual Member States and benchmark them against the EU average (EC 2017b, p. 5).

\section{Positions of Latvia and Lithuania within the EU with regard to e-commerce}

At present, Denmark, Sweden, Finland and the Netherlands have the most advanced digital economies and societies in the EU, followed by Luxembourg, Ireland, the UK, Belgium and Estonia. Romania, Greece and Italy have the lowest scores on the DESI. In 2018, the DESI scores ranged from 71.7 (Denmark) to 37.5 (Romania) (EC 2018b); the median was 54.6 , and the mode was in the range of 50.8-60.7. The positions of all the Baltic States (Estonia - 59, Latvia - 56.6, Lithuania - 50.8) were within the range of the mode. An analysis of the DESI components associated with or directly related to e-commerce reveals that the situation is less favourable. As shown in Tables 1 and 2, Estonia has succeeded in reaching EU averages, while Lithuania reached some of them. Latvia, unfortunately, lagged behind considerably in terms of EU averages pertaining to e-commerce.

Table 1. Use of Internet services for shopping (value indicator), 2014-2018

\begin{tabular}{|l|c|c|c|c|c|c|c|}
\hline 3c2 - Shopping & Estonia & Latvia & Lithuania & EU-28 & Denmark & Sweden & Finland \\
\hline 2014 & 57.0 & 44.0 & 36.0 & 63.0 & 81.0 & 80.0 & 73.0 \\
\hline 2018 & 65.0 & 55.0 & 49.0 & 68.0 & 82.0 & 84.0 & 75.0 \\
\hline Change & +8.0 & +11.0 & +13.0 & +5.0 & +1.0 & +4.0 & +2.0 \\
\hline
\end{tabular}

Source: authors' calculations based on the Digital Economy and Society Index (DESI) for 2018.

Of course, the numbers of users of Internet shopping services have increased in all the three Baltic States at a higher rate than on average in the EU, which confirms significant progress in this area. Nevertheless, much has to be done to reach the EU average, and the level of the Nordic countries in particular, as the Baltic States are included in this country group for the assessment of digitalisation performance. It is confirmed by the indicator values for Internet services for shopping in Denmark, Sweden and Finland. 
E-commerce as a Consequence of Innovat on and the Cause of New Innovat ons for SMEs...

Table 2. Linear and horizontal comparison of integration in e-commerce (indicator value), 2014-2018

\begin{tabular}{|l|r|r|r|r|c|c|c|}
\hline 4b1 - SMEs selling online & Estonia & Latvia & Lithuania & EU-28 & Denmark & Sweden & Finland \\
\hline 2014 & 12.0 & 6.9 & 18.0 & 15.0 & 26.0 & 24.0 & 14.0 \\
\hline 2018 & 15.4 & 10.6 & 21.9 & 17.2 & 27.8 & 28.5 & 19.6 \\
\hline Change & +3.4 & +3.7 & +3.9 & +2.2 & +1.8 & +4.5 & +5.6 \\
\hline $\begin{array}{l}\text { 4b2 - E-commerce } \\
\text { turnover }\end{array}$ & Estonia & Latvia & Lithuania & EU-28 & Denmark & Sweden & Finland \\
\hline $2014 \quad 13.0$ & 7.6 & 7.4 & 8.8 & 14.0 & 14.0 & $\ldots$ \\
\hline 2018 Change & 11.4 & 8.6 & 11.8 & 10.3 & 14.5 & 15.0 & $\ldots$ \\
\hline $\begin{array}{l}\text { 4b3 - Selling online } \\
\text { cross-border }\end{array}$ & -1.6 & +1.0 & +4.4 & +1.5 & +0.5 & +1.0 & $\ldots$ \\
\hline 2014 & Estonia & Latvia & Lithuania & EU-28 & Denmark & Sweden & Finland \\
\hline 2018 & 5.5 & 4.1 & 11.0 & $\mathbf{6 . 5}$ & 9.9 & 7.7 & 4.8 \\
\hline Change & 8.3 & 4.7 & 12.4 & 8.4 & 9.2 & 9.7 & 5.9 \\
\hline
\end{tabular}

Source: authors' calculations based on the EC (2019) Countries' Performance in Digitisation.

SMEs represent $99 \%$ of all businesses in the EU and are the most important sources of employment (EC 2018a). For this reason, promoting innovative economic activities is a priority, while one of the kinds of innovative activity this century is the expansion of e-commerce among SMEs. The authors' calculations showed that performance in digitisation has improved in the EU Member States. The number of micro-, small and medium enterprises, which represent SMEs, who were engaged in e-commerce had increased, as had net turnover and cross-border online selling. Linear e-commerce growth was observed both in the EU as a whole and in any Member State. However, individual Member States could be divided by development level into categories, beginning with innovation leaders, strong innovators and moderate innovators, through to modest innovators. Since the European Ecommerce Association includes Denmark, Sweden and Finland (innovation leaders) and all the three Baltic States - Estonia, Latvia and Lithuania (moderate innovators) - in the group of Nordic countries, the authors selected the previously-mentioned countries for analytical comparison (Table 2). Each country analysed had some differences regarding the research problem. The growth rates for SME online selling and cross-border online selling differed. In 2014, among the innovation leaders, only Denmark dominated, while in 2018, Sweden outpaced Denmark. Among the Baltic States, Lithuania performed the best in SME e-commerce. However, the most important conclusion is that e-commerce is expanding in all the economic activities of SMEs in all the Baltic States, slowly approaching the level of Nordic leaders with regard to this innovative activity. A logical question arises - what contributes to and hinders the expansion of e-commerce in the economic activities of SMEs the most. The second part of the research focuses on answering the question. 


\section{The e-commerce system as a supply and demand interaction}

\section{E-commerce as a system}

A system is an arrangement or collection of objects that operate together for a common purpose. The objects may represent machines, humans, as well as physical and biological entities. E-commerce, in essence, is a system comprised of at least three elements: a supplier of a good/service, the good or service itself and the buyer of the good/service. This system effectively functions only when the supplier and the buyer interact and the wishes of both parties more or less coincide, which manifests itself in a successful offer of goods/services and the active demand for the goods/services.

Most scientists see this system as a set of system components, one of which is the technological-economic component. It includes the availability of the Internet, the financial capacity to purchase necessary hardware, the availability of ICT specialists and the digital skills of the personnel. Other components are socio-economic, and they include the skills of the population to use the Internet, their interest in e-shopping to reduce the cost of a good/service, the opportunity to compare a good/service and the gains from various shopping sites. The uniting element of the two sides, or the third component, is a good or service, whose creators want to sell it in as large quantities as possible and earn the highest profit, while the buyers want to get the cheapest good/ service and, at the same time, of the highest quality (see, e.g., Schallmo et al. 2017; Schill et al. 2019; Verhoef 2012). Of course, some researchers give broader and more complex characteristics of the e-commerce system, dividing it into two subsystems - the production ecosystem and the consumption ecosystem, which are mutually interdependent (Subramaniam et al. 2019). Such a system model involves machines, humans, as well as physical and biological entities. However, the expansion of a digital contact network, an increase in the number of related specialists and users and, consequently, the growth of e-commerce on a global scale explicitly contribute to achieving the goal. Since our research on e-commerce as a system is based on a sociological survey, an analysis of the survey results allowed us to construct a human-focused model for the e-commerce system.

\section{Positive and problematic aspects of e-commerce from the perspective of suppliers}

Any human action is determined by a motivation that is oriented towards achieving certain goals. Representatives (owners or employees) of small and large SMEs were involved in the survey as e-commerce suppliers of goods/services. Summarising the opinions of the SMEs surveyed, the authors gained an insight into their motives for doing e-commerce, the economic contribution of e-commerce as well as the problems arising from this economic activity. 
E-commerce as a Consequence of Innovation and the Cause of New Innovations for SMEs...

Table 3. Motives of suppliers of goods/services for doing e-commerce

\begin{tabular}{|l|c|c|}
\hline $\begin{array}{c}\text { For what purposes does your enterprise use the Internet environment? } \\
\text { (several answers possible) }\end{array}$ & Latvia & Lithuania \\
\hline Advertising & 11.6 & 88.2 \\
\hline Selling goods or services & 81.1 & 76.5 \\
\hline Communication with customers & 74.7 & 82.4 \\
\hline
\end{tabular}

Source: own elaboration.

Both Latvian and Lithuanian SMEs quite equally rated the use of e-commerce for selling goods/services and communicating with customers (Table 3). At the same time, the views on the role of the Internet in advertising goods/services were very different. The Lithuanian respondents considered the use of the Internet to be important for all the three purposes, yet they slightly preferred advertising goods/services to the other options. The Latvian respondents preferred to use the Internet for selling their goods/ services. They placed communication with the buyers of their goods/services in second place and assigned a minimum role to advertising their goods/services. It is likely that this factor, in particular, contributed to the better performance of the Lithuanian respondents in e-commerce, as mentioned above (Table 2).

Table 4. Effects of the use of the e-environment on the economic performance of businesses

\begin{tabular}{|l|r|c|}
\hline \multicolumn{1}{|c|}{$\begin{array}{c}\text { To what extent does e-environment use improve the economic } \\
\text { performance of a business? }\end{array}$} & Latvia & Lithuania \\
\hline Meaningfully & 63.1 & 35.3 \\
\hline Partly & 29.5 & 52.9 \\
\hline Makes a minor contribution & 7.4 & 11.8 \\
\hline
\end{tabular}

Source: own elaboration.

The surveyed suppliers of goods/services positively viewed the engagement of SMEs in e-commerce, pointing out that the use of the e-environment enhanced the economic performance of business. This opinion was supported by both the Latvian and Lithuanian respondents (Table 4). However, the respondents' opinions on the economic contribution of e-commerce differed between the countries significantly. Almost two-thirds of the Latvian respondents considered the economic contribution of e-commerce to be very significant, while only a third of the Lithuanian respondents had the same opinion. The opinion of the Latvian suppliers of goods/services could be explained by the fact that among the Baltic States, the strongest increase in online selling was reported in Latvia ( +16 percentage points in Latvia, +7 percentage points in Lithuania and +9.5 percentage points in Estonia), and this fact created this positive opinion, even though the increase in e-commerce turnover was larger in Lithuania than in Latvia (Table 2).

Like any economic activity, e-commerce provides gains as well as creates problems for suppliers of goods/services. Identifying the most important problems makes it possible to find solutions to the problems (Table 5). 
Table 5. E-commerce issues in the view of the product/service vendor

\begin{tabular}{|l|c|c|}
\hline $\begin{array}{c}\text { If entrepreneurs do not actively use e-commerce sufficiently, what } \\
\text { are the reasons for this? (several answers possible) }\end{array}$ & Latvia & Lithuania \\
\hline Too expensive & 16.8 & 0 \\
\hline No effective method & 27.4 & 17.6 \\
\hline No understanding of e-commerce & 23.2 & 41.2 \\
\hline No specialists engaged in it & 36.8 & 35.3 \\
\hline Other reasons & 0 & 5.9 \\
\hline
\end{tabular}

Source: own elaboration.

The Latvian and Lithuanian respondents' opinions on the key problems that hinder this kind of economic activity were similar but also quite different. The respondents shared the opinion that there was a lack of IT specialists able to digitalise the sale of goods/services and effectively manage e-commerce activities. This problem could be caused by an insufficient number of IT specialists in these countries, and there is a need to contribute to education in this particular field. The problem could also be due to the financial capacity of SMEs - they were not able to provide adequate remuneration to IT specialists or cover the cost of training courses for their employees who were ready to build up their knowledge of and skills in business digitalisation. The respondents also pointed to the lack of understanding of e-commerce as such among the general public. This problem was particularly stressed by the Lithuanian respondents, who prioritised it in their country.

\section{Positive and problematic aspects of e-commerce from the perspective of buyers}

Buyers of goods/services use e-commerce to achieve certain goals, i.e. the acquisition of goods or services they are interested in.

Table 6. The most popular products bought online (\% of total respondents)

\begin{tabular}{|l|c|c|}
\hline \multicolumn{1}{|c|}{ If you buy online, what are you buying the most? } & Latvia & Lithuania \\
\hline Tickets for public events and entertainment & 43.5 & 56.5 \\
\hline Insurance & 43.3 & 56.7 \\
\hline Consumer electronics (TV, washing machine, etc.) & 31.6 & 68.4 \\
\hline Clothing and accessories & 39.6 & 60.4 \\
\hline Mobile phones, tablets and gadgets & 25.8 & 74.2 \\
\hline
\end{tabular}

Source: own elaboration.

The survey results revealed that there were two distinct differences in buyer behaviour between the countries (Table 6). First, the proportion of buyers who purchased both goods and services, regardless of the kinds of products they bought, was higher in Lithuania than in Latvia; second, the overall demand for online shopping was considerably higher in Lithuania than in Latvia. In Latvia, most respondents pur- 
chased tickets for public events and entertainment, while in Lithuania, most respondents bought mobile phones, tablets and gadgets. Applying a ranking method revealed that the smallest difference in demand for online shopping between both countries was observed for tickets for public events and entertainment (13 percentage points), whereas the largest difference (48.4 percentage points) was found for mobile phones, tablets and gadgets. An analysis of the top two products bought online revealed that in Latvia, buyers preferred purchasing services, whereas in Lithuania, they preferred buying goods. Identifying the effect of this difference on e-commerce turnover is the next specific tasks of the present research.

According to the Latvian and Lithuanian respondents, the availability of information on the Internet was the key reason for shopping online. More than half of the respondents in both countries pointed out that e-commerce provided lower prices on goods/services than conventional commerce did. The difference in percentage between the countries was only a few points. There were very different opinions on whether the available Internet information on goods and services was sufficient. The Lithuanian respondents more positively rated the available Internet information on goods/services (21.9 percentage points higher than the Latvian respondents). It is likely that the reason was the low role assigned by Latvian suppliers to advertising goods/services (Table 7).

Table 7. Consumer benefits from online shopping

\begin{tabular}{|l|c|c|}
\hline \multicolumn{1}{|c|}{ Problems of online shoppers in the digitalised market } & Latvia & Lithuania \\
\hline Inability to find the good/service what you were looking for & 18.0 & 31.2 \\
\hline Lack of information about the good/service, delivery, payment options etc. & 41.0 & 32.5 \\
\hline Delivery is too long & 42.6 & 36.4 \\
\hline
\end{tabular}

Source: own elaboration.

It is not only suppliers of goods/serviced that face problems in e-commerce. E-commerce creates problems for buyers, as well. The most negative aspects, according to the respondents of both countries, were too long delivery time and insufficient information about the good/service available on the Internet (Table 8). The Latvian respondents had a more negative opinion than the Lithuanian respondents. The latter stressed the wish to have a broader assortment of goods/services available on the Internet, which meant that a more diverse spectrum of SMEs would have to engage in e-commerce. This kind of wish was less pronounced in Latvia.

In economic theory, perfect markets have been associated with possessing perfect information, that is to say, a situation in which all consumers and producers have perfect knowledge of the price, utility, quality and production methods of products. A perfect market is an ideal. Real markets do not normally display perfect market conditions; they range from those that are closer to the ideal to farther away (Improving... 2016). The survey revealed that e-commerce in Lithuania, and especially in Latvia, was on its way to becoming a perfect e-market. 
Table 8. Problems of online shoppers in the digitalised market

\begin{tabular}{|l|c|c|}
\hline \multicolumn{1}{|c|}{ Consumer benefits from online shopping } & Latvia & Lithuania \\
\hline To access different offers more easily & 50.8 & 72.7 \\
\hline Information is always available on the Internet & 67.2 & 68.8 \\
\hline Cheaper than in a traditional store & 50.8 & 53.2 \\
\hline
\end{tabular}

Source: own elaboration.

\section{Opportunities to improve the interaction between suppliers and buyers}

The desirable result of the interaction between suppliers and buyers is the effective functioning of e-commerce as a system. Applying the paradigmatic method and analogical comparison allowed us to assess the interaction between suppliers and buyers (Table 9).

Table 9. Comparison of positive and problematic aspects from the perspectives of suppliers and buyers

\begin{tabular}{|l|l|}
\hline \multicolumn{1}{|c|}{ Suppliers } & \multicolumn{1}{|c|}{ Buyers } \\
\hline $\begin{array}{l}\text { Positive aspects } \\
\text { E-commerce gives an opportunity to communi- } \\
\text { cate withers and increase net turnover }\end{array}$ & Positive aspects \\
\hline $\begin{array}{l}\text { Problematic aspects } \\
\text { Lack of specialists: } \\
\text { prepared by education institutions } \\
\text { enterprise personnel with necessary skills }\end{array}$ & $\begin{array}{l}\text { Problematic aspects } \\
\text { Information about the good/service is available } \\
\text { on the Internet, yet it is either insufficient } \\
\text { in content or not specific (SMEs currently do not } \\
\text { offer some goods/services via e-commerce) }\end{array}$ \\
\hline
\end{tabular}

Source: own elaboration.

Digital infrastructure for communication is the foundation for a dynamic business ecosystem and is of great importance for SMEs. The practical application of the infrastructure both in the technical and content aspects opens the way for distance marketing not only in the domestic market but also in the single EU market and the global market (OECD 2019). Research has found that as the demand for goods/ services grows, consumers increasingly want a wider assortment of goods/services and also change in the assortment (Lee et al. 2019, pp. 264-275). In view of the growing number of e-commerce users, the structuring of buyers who differ in terms of interests and financial capacity is increasingly being observed (Schill et al. 2019, pp. 317-327).

The comparison of problematic aspects in e-commerce from the perspectives of Latvian and Lithuanian respondents (suppliers and buyers) has focused on the interaction of the e-marketing parties through communication. Accordingly, the conclusion drawn by the research is sufficiently important to seek solutions to enhance the interaction of suppliers and buyers. One of the options, of course, is the enhancement 
of the education system, so that young individuals entering the labour market have sufficient IT skills. This would contribute to the expansion of e-commerce among SMEs, micro-enterprises in particular. The second option pertains to improving the professionalism of current enterprise personnel - including their marketing and advertising skills. This, in turn, would allow them to meet the expectations of various social groups, as their wishes are not homogeneous. In both cases, new, innovative solutions should be sought to achieve positive change (Westlund et al. 2013). Implementing both options would provide more opportunities for cross-border e-commerce, as Latvia and Lithuania are countries with small domestic markets.

Commerce is a traditional phenomenon that has existed for millennia. The $21^{\text {st }}$ century has brought a new kind of commerce - e-commerce that, combining the traditional and the modern, requires new skills from both suppliers and buyers in order that both parties achieve the desired result through mutual communication. For this reason, a comparison and assessment of the opinions of suppliers and buyers of goods/ services was important.

\section{Conclusions}

1. Integration in e-commerce in Latvia and Lithuania has expanded in recent years, approaching the EU averages. Lithuania has even exceeded some EU averages. Reaching the levels of Denmark, Sweden and Finland, which are leaders in the group of Nordic countries, requires much effort, and both quantitative and qualitative changes need to be achieved. This indicates that solutions could be found to improve e-commerce as a system in the countries examined.

2. In the opinion of the manufacturers involved in the e-commerce system, the biggest problem is the lack of adequately trained specialists who are not only familiar with the use of technologies but who also have communication skills with consumers and creative ideas for high-quality advertising of goods or services. Additionally, they should speak a foreign language required for the expansion of cross-border trade in addition to the official language of the country they are doing business in. Accordingly, one of the ways to improve the e-commerce system is to expand the preparation of qualified specialists who have a broad socio-technological knowledge to perform their tasks.

3. Consumers who shop online, i.e. those who participate in an e-commerce system as shoppers, identify two major problems. First, there is a lack of information about the product/service itself that is supplied by the manufacturer/service provider. This is particularly true regarding certain types of product/service (concert tickets, mobile phones, clothing or food). Second, the buyer wants to get information not only on the amount to be paid but also on the possible payment method. The results of the survey clearly indicated the need to improve the amount and quality of information that the manufacturer/service provider makes avail- 
able online, which pointed to another, very important development path for this e-commerce system.

4. The research results revealed that Latvia lagged behind the other countries. The Lithuanian respondents (both suppliers and buyers) viewed e-commerce more positively than the Latvian respondents did. Compared with the Lithuanian respondents, the Latvian respondents (both suppliers and buyers) identified more problems in e-commerce. However, the problems in the e-commerce system were identified by the respondents in both countries, which confirmed the need to improve the interaction between suppliers and buyers of goods/services within e-commerce as a system. The interaction represents the amount and, most importantly, the quality of information available online. Increasing the amount of information and, above all, improving the quality is a priority for suppliers of goods/services.

\section{Acknowledgements}

The paper was financially supported by the National Research Programme project INTERFRAME-LV.

\section{References}

Berg, J., Furrer, M., Harmon, E., Rani, U., Silberman, M. (2018), Digital labour platforms and the future of work. Towards decent work in the online world. ILO, Geneva. P. 160, https://www.ilo.org/wcmsp5/groups/public/---dgreports/---dcomm/---publ /documents/publication/wcms_645337.pdf (accessed: 15.11.2019).

Byungjoon, Y., Moonkyoung, J. (2019), A bibliographic survey of business models, service relationships, and technology in electronic commerce, "Electronic Commerce Research and Applications”, 33 (2019), 100818. https://doi.org/10.1016/j.elerap.20 18.11.005

Digital Transformation of Business Models - Best Practice, Enablers, and Roadmap. "International Journal of Innovation Management", 21 (8), (December 2017) 1740014 (17 pages). https://doi.org/10.1142/S136391961740014X

European Commission (2010), Europe 2020: a European Strategy for Smart, Sustainable and Inclusive Growth. Brussels. http://ec.europa.eu/eu2020/pdf/COMPLETEN BARROSO007-Europe2020-EN version.pdf (accessed: 5.12.2019).

European Commission (2014), Digital Economy and Society Index (DESI), https://digi tal-agenda-data.eu/datasets/http-semantic-digital-agenda-data-eu-dataset-lead-in dicators/indicators (accessed: 24.11.2019).

European Commission (2017a), Digital Single Market strategy: - Mid-term review, https://eur-lex.europa.eu/content/news/digital_market.html (accessed: 5.01.2020). 
European Commission (2017b), Digital Economy and Society Index (DESI). Methodological note, http://ec.europa.eu/information_society/newsroom/image/document/20 18-20/desi-2018-methodology_E886EDCA-B32A-AEFB-07F5911DE975477B_522 97.pdf (accessed: 30.11.2019).

European Commission (2018a), European Innovation Scoreboard. International Market. Industry. Entrepreneurship and SMEs, https://ec.europa.eu/growth/industry/in novation/facts-figures/scoreboards_en (accessed: 27.12.2019).

European Commission (2018b), Countries performance in digitisation, https://ec.eu ropa.eu/digital-single-market/en/countries-performance-digitisation (accessed: 14.12.2019).

European Ecommerce Report (2018), European ecommerce association, https://www .scribd.com/document/383111825/European-Ecommerce-Report-2018 (accessed: 12.01.2020).

Eurostat regional yearbook (2018), https://ec.europa.eu/eurostat/publications/statisti cal-books/regional-yearbook (accessed: 17.12.2019).

Global Forum on Agriculture (2018), Digital technologies in food and agriculture: reaping the benefits. 14-15 May 2018, OECD Conference Centre, Paris. http://www.oe cd.org/tad/events/Background\%20note_Website.pdf (accessed: 24.11.2019).

Grass, K., Weber, E. (2017), EU 4.0 - The debate on digitalisation and the labour market in Europe, IAB Discussion Paper 201639, https://ideas.repec.org/p/iab/iabdpa /201639_en.html (accessed: 6.01.2020).

Improving Market outcomes. Enhancing the Position of Farmers in the Supply Chain (2016), Report of the Agricultural Markets Task Force, EC, Brussels. https://ec.euro pa.eu/agriculture/sites/agriculture/files/agri-markets-task-force/improving-marke ts-outcomes_en.pdf (accessed: 6.01.2020).

Lee, Y.J., Ha, S., Johnson, Z. (2019), Antecedents and consequences offlow state in e-commerce, "Journal of Consumer Marketing", 36 (2), pp. 264-275. https://doi.org/10.11 08/JCM-10-2015-1579

Pytkowska, J., Korynski, P. (2017), Digitalizing Microfinance in Europe. Research paper. Microfinance Centre, Poland. https://www.european-microfinance.org/sites/de fault/files/document/file/Digitalization-research-paper.pdf (accessed: 16.11.2019).

Raisová, M., Ćurpová, J. (2014), Economic growth-supply and demand perspective, "Economics and Finance", 15, pp. 184-191, http://www.sciencedirect.com (accessed: 6.11.2019).

Schallmo, D., Williams, Ch.A., Boardman, L. (2017), Digital Transformation of Business Models - Best Practice, Enablers, and Roadmap, "International Journal of Innovation Management”, 21 (8), (December 2017) 1740014 (17 pages). https://www .worldscientific.com/doi/pdfplus/10.1142/S136391961740014X (accessed: 6.11.2019).

Schill, M., Godefroit-Winkel, D. (2019), Consumer segments in the smart environmental objects market, "Journal of Consumer Marketing”, 36 (2), pp. 317-332. https:// doi.org/10.1108/JCM-12-2017-2472

Subramaniam, M., Iyer, B., Venkatraman, V. (2019), Competing in digital ecosystems, "Business Horizons", 62, pp. 83-94. https://doi.org/10.1016/j.bushor.2018.08.013

TUAC (2017), Digitalisation and the Digital Economy. Trade Union Key Messages. http://www.tuac.org (accessed: 27.11.2019). 
Verhoef, P. (2012), Customer based marketing strategy, https://www.elgaronline.com /view/9781849800983.00017.xml (accessed: 7.12.2019).

Waas, B., Pavlou, V. and Gramano, E. (2018), Digital economy and the law: introduction to this Special Issue, "Work organisation, labour \& globalisation", 12 (2), Winter 2018, pp. 7-11. https://doi.org/10.13169/workorgalaboglob.12.2.0007

Westlund, H., Andersson, M., Karlsson, Ch. (2013), Creativity as an integral element of social capital and its role for economic performance, "CESIS Electronic Working Paper Series”. Paper No. 330, https://static.sys.kth.se/itm/wp/cesis/cesiswp330.pdf (accessed: 20.10.2019).

\section{Streszczenie}

\section{Handel elektroniczny jako konsekwencja innowacji i przyczyna nowych innowacji dla MŚP: perspektywy Łotwy i Litwy}

Pojawienie się nowych technologii i rozwój cyfryzacji stworzyły okazję dla rozwoju handlu elektronicznego. Dostawca i nabywca towarów i usług spotykają się w środowisku elektronicznym i rozwiązują swoje problemy bez bezpośredniego kontaktu, przynosząc wzajemne korzyści. W UE i w krajach badanych przez niniejsze badanie MŚP stanowią większość ogółu przedsiębiorstw. W związku z tym handel elektroniczny (e-handel) jako system, w świetle globalizacji, staje się ważnym priorytetem badawczym, a ocena tego z perspektywy dostawców i nabywców jest szczególnym zadaniem niniejszego badania. W niniejszym badaniu wykorzystano dane Eurostatu, OECD i Centralnego Biura Statystycznego Łotwy, a także dane autorów z ankiety (użytkownicy handlu elektronicznego: dostawcy $(n=112)$ i nabywcy $(n=138$ ) towarów i usług) przeprowadzenego na Łotwie i Litwie. Analiza danych pozwoliła stwierdzić, że pozytywne i negatywne perspektywy badanego zjawiska zostały podane zarówno przez dostawców, jak i nabywców. Z tego powodu istnieje potrzeba zmotywowania społeczeństwa jako całości i struktur zarządzania na wszystkich szczeblach, aby uzgodnić nowoczesność z tradycyjną, co jest spowodowane ekspansją handlu elektronicznego.

Słowa kluczowe: handel elektroniczny, MŚP, innowacje, motywacja 